\title{
The sensitivity of intense rainfall to aerosol particle loading - a comparison of bin-resolved microphysics modelling with observations of heavy precipitation from HyMeX IOP7a
}

\author{
Christina Kagkara, Wolfram Wobrock, Céline Planche, and Andrea I. Flossmann \\ Université Clermont Auvergne, CNRS, Laboratoire de Météorologie Physique, 63000 Clermont-Ferrand, France
}

Correspondence: Wolfram Wobrock (wolfram.wobrock@uca.fr) and Céline Planche (celine.planche@uca.fr)

Received: 28 September 2019 - Discussion started: 10 October 2019

Revised: 27 March 2020 - Accepted: 8 April 2020 - Published: 27 May 2020

\begin{abstract}
Over the Cévennes-Vivarais region in southern France $5 \mathrm{~h}$ intensive rainfall covering an area of $1000 \mathrm{~km}^{2}$ with more than $50 \mathrm{~mm}$ of rain accumulation was observed during IOP7a of HyMeX. This study evaluates the performance of a bin-resolved cloud model for simulating this heavy-precipitation event. The simulation results were compared with observations of rain accumulation, radar reflectivity, temporal and spatial evolution of precipitation, 5 min rain rates, and raindrop size distributions (RSDs). The different scenarios for aerosol number concentrations range from 1000 to $2900 \mathrm{~cm}^{-3}$ and represent realistic conditions for this region. Model results reproduce the heavy-precipitation event with respect to maximum rain intensity, surface area covered by intense rain and the duration, as well as the RSD. Differences occur in the short-term rainfall rates, as well as in the drop number concentration. The cloud condensation number concentration has a notable influence on the simulated rainfall, on both the surface amount and intensity but also on the RSD properties, and should be taken into account in microphysics parameterizations.
\end{abstract}

\section{Introduction}

Heavy precipitation often occurs in autumn in the CévennesVivarais (CV) region in southern France, frequently resulting in casualties in part due to difficulties of operational weather forecast models to predict location, timing and amplitude for timely alerts (e.g. Sénési et al., 1996; Romero et al., 2000; Delrieu et al., 2005; Silvestro et al., 2012; Rebora et al., 2013). In order to evaluate the performance of precipitation forecast models, typically radar observations and/or rain gauge measurements are used. Among other instruments, both types of observations were available during the HyMeX campaign (Ducrocq et al., 2014) from September to early November 2012 over the western part of the Mediterranean Sea. The current study evaluating the model performance will focus on data from IOP7a (intense observation period) observed on 26 September 2012 as it represents the best-documented observational period of intensive rain during HyMeX for the Cévennes-Vivarais region with numerous measurements of precipitation microphysics.

Other modelling studies of heavy-precipitation forecasts using several intensive observational periods during HyMeX were already performed by Hally et al. (2014) for IOP6 and 7a, Duffourg et al. (2016) and Martinet (2017) for IOP16a, and Taufour et al. (2018) for IOP6 and 16a. Part of these studies focused on the role of dynamical and microphysical processes responsible for heavy-precipitation formation; others investigated how the microphysics parameterization impacts modelled rain-forming processes and rain amounts. All studies produced heavy-rain events; however sometimes significant differences in location, intensity or microphysical characteristics between model results and observations seem to indicate remaining deficiencies in the physical description of cloud and precipitation formation.

Weather forecast models like the Integrated Forecasting System (IFS) of the European Centre for Medium-Range Weather Forecasts (ECMWF) use, in general, bulk parameterizations of the cloud microphysical processes, which treat condensational and collision processes, formation of ice, and interaction between the ice and liquid phase but greatly simplify the dependency of cloud microphysical processes on 
hydrometeor sizes (Ahlgrimm and Forbes, 2014). More sophisticated bulk parameterizations, as deployed in models like Weather Research and Forecasting (WRF) (Thompson et al., 2008; Morrison et al., 2012), COSMO (Seifert, 2008) or Meso-NH (Vié et al., 2016), use two- or even three-moment schemes wherein the spectra of cloud and rain droplets as well the spectra of ice crystals and precipitating ice particles are prescribed by exponential or gamma distributions. In particular, the model studies performed in the HyMeX context applied the one-moment ICE3 scheme (Pinty and Jabouille, 1998), and the work of Taufour et al. (2018) compares the two-moment scheme LIMA (Vié et al., 2016). The form of these prescribed spectra can deviate considerably from observed ones, although several simulated bulk parameters, like radar reflectivity, rain and ice water content, can sometimes give values similar to the observations. Studies of Varble et al. (2014) and Taufour et al. (2018) highlight the discrepancies between observed surface raindrop spectra and those simulated with one- or two-moment microphysics schemes.

Another technique to simulate clouds is the use of socalled bin microphysics schemes. Until now, only a few models have been available to simulate, in a size-resolved manner, the spectra of drops and ice particles from a few micrometres to several millimetres (Geresdi, 1998; Khain et al., 2004; Lynn et al., 2005; Planche et al., 2010) in a 3D mesoscale context due to the often prohibitive computational costs of memory and CPU (central processing units). This detailed methodology, however, allows better insights into the evolution of cloud-specific processes such as phase changes and collisional processes and describes more closely the interactions with the field of water vapour and temperature and its feedback with cloud dynamics.

Only a few studies (e.g. Iguchi et al., 2008; Fan et al., 2012) have been focused on real deep convective systems with a bin microphysics scheme in a 3D dynamical framework, and none of them were applied to an intense precipitating system as usually observed in autumn over the western Mediterranean basin. One major objective of this study is, thus, to test if a bin-resolved microphysics module in a 3D mesoscale model is able to reproduce a real case of intense precipitation using the dataset obtained during IOP7a of HyMeX. This can then help in the future to improve the bulk models that rely on many more assumptions and approximations to predict intense precipitation, in particular regarding the rain maxima requiring alerts for the population, due to the constraints of the prescribed spectra (Flossmann and Wobrock, 2019). We focus more specifically on the following questions: is a detailed cloud description (i.e. bin-resolved modelling) for all hydrometeor spectra suited to quantitatively reproduce rain accumulations, rain size distribution, and spatial and temporal variability that were observed by rain gauges, disdrometers and ground radars?

A further objective is to investigate the influence of aerosol number concentration on surface precipitation and raindrop spectra as it is well known that cloud formation depends on the presence of atmospheric aerosol particles acting as cloud condensation nuclei and ice-nucleating particles (CCN and INPs, respectively). Until now, only a few 3D cloud models (see e.g. Leroy et al., 2009; Thompson and Eidhammer, 2014; Vié et al., 2016; Marinescu et al., 2017 and Shpund et al., 2019, among others) have explicitly considered aerosol particles in the hydrological cycle, and their model results demonstrated the potential influence of the aerosol concentration on cloud and precipitation development. The bin cloud model DESCAM (Detailed Scavenging Model; Flossmann and Wobrock, 2010) used in this study follows this approach by forecasting the size distribution of interstitial aerosols and residual aerosols in drops and ice crystals. Aerosol-cloud modelling, however, needs initial information about cloud condensation nuclei prevailing in the atmosphere prior to the cloud development. These data were available during HyMeX as measurements of the aerosol particle spectra were performed by ground-based and airborne observations during the entire experimental period.

The dynamics and microphysics model used in this study, its geographical set-up, and initial and boundary conditions are described in Sect. 2. In Sect. 3 the different data used for the comparison with the model outputs from different observational platforms providing rain parameters and measurements of the prevailing aerosol particle concentrations are presented. The current comparisons will focus on the large number of surface observations for the rain while the comparison with airborne data in order to analyse the in-cloud features will be presented in future work.

The comparison between simulated rain accumulations and results of the quantitative precipitation estimate (QPE) for IOP7a (Boudevillain et al., 2016) is given in Sect. 4. Section 4 also presents the temporal evolution of 5 min rain rates recorded from numerous rain gauge stations, which are analysed, and their evolution is compared to the modelled ones. Finally, in Sect. 5, simulated raindrop spectra are confronted with observed ones from disdrometer measurements. Section 6 summarizes the findings and conclusions of this study.

\section{Model configuration and model set-up}

For this study we use the detailed microphysics model DESCAM (Detailed Scavenging Model; Flossmann and Wobrock, 2010) which is driven by the 3D dynamics of the anelastic and non-hydrostatic model of Clark et al. (1996) and Clark (2003). Initial and boundary conditions for horizontal wind, temperature and water vapour mixing ratio were provided by the ECMWF IFS data products at 00:00 and 12:00 UTC, 26 September 2012. An ensemble study of IOP7a with the mesoscale model Meso-NH (Hally et al., 2014) showed that the application of the ECMWF IFS data reproduces onset and evolution of this precipitation event relatively well. The location of the domains for the numerical simulation is depicted in Fig. 1. The outermost model has 


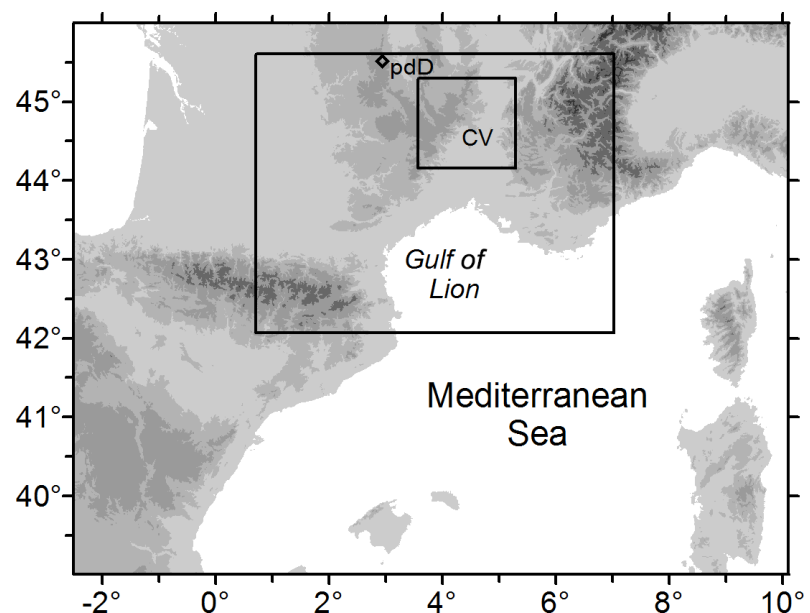

Figure 1. Map of the three model domains. CV corresponds to the region of Cévennes and Vivarais and pdD to the Global Atmosphere Watch station at the puy de Dôme station. The grey contours display elevations larger than 2, 500, 1000, 2000 and $3000 \mathrm{~m}$.

a horizontal grid resolution of $8 \mathrm{~km}$, and for the nested domains the grid size resolution increases to 2 and $0.5 \mathrm{~km}$, respectively. The vertical grid $z$ is terrain following and nonequidistant. Next to the surface $\Delta z$ is about $40 \mathrm{~m}$ and increases to $230 \mathrm{~m}$ at $9 \mathrm{~km}$ (the outermost model uses a coarser grid, where only every second grid point of the inner vertical grid is used). The outermost domain extends up to $23.5 \mathrm{~km}$; the second and the innermost domains end at $12.5 \mathrm{~km}$. Twoway nesting was applied for all forecast parameters including the spectra of aerosols and hydrometeors. The simulations in all domains were integrated with a time step of $2 \mathrm{~s}$.

A microphysical scheme, such as DESCAM, calculates the temporal and spatial changes in the number concentration functions of aerosol particles, droplets and ice particles as well as the mass distribution of the residual aerosol in drops and in ice crystals. Each distribution function is resolved by 39 classes or size bins, resulting in 195 additional prognostic variables for the numerical model (Leroy et al., 2009). All hydrometeor spectra use a logarithmically equidistant spaced mass coordinate. The resulting drop size categories cover a diameter range from $2 \mu \mathrm{m}$ to about $10 \mathrm{~mm}$, aerosol spectra range from $1 \mathrm{~nm}$ to $7 \mu \mathrm{m}$. For ice crystals the conversion of the mass bins to diameter depends on the chosen massdiameter relationship (Fontaine et al., 2014). Droplets form when supersaturation occurs, and a subset of the aerosol particles becomes cloud condensation nuclei. After a period of condensational growth, larger drop sizes form, initiating collision and coalescence and thus the formation of precipitating drops. Droplets and also aerosols can form ice particles due to heterogeneous and homogeneous nucleation (Meyers et al., 1992; Koop et al., 2000). The growth of the ice crystals due to deposition of water vapour is treated size dependently and explicitly as a function of the predicted ice supersaturation (i.e. temperature and water vapour mixing ratio). Finally,
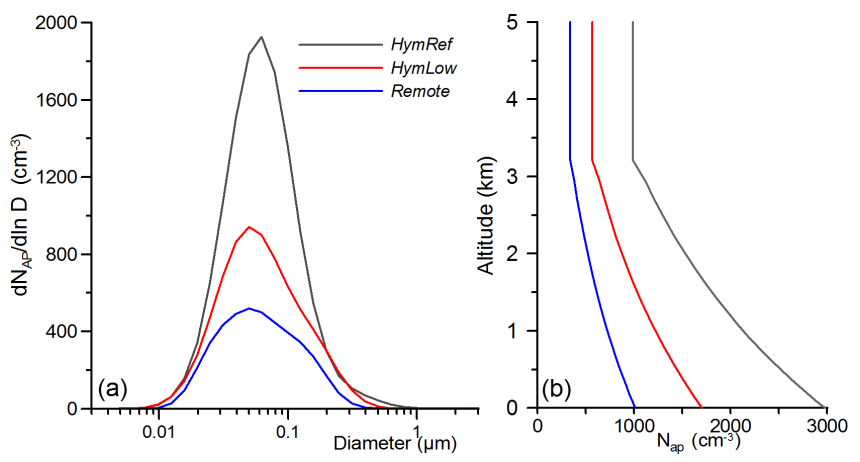

Figure 2. (a) Number distribution of initial aerosol particles for the three scenarios. (b) Initial vertical profiles of the total number of aerosol particles.

the collection processes between water and ice (riming) and ice crystals only (aggregation) are also taken into account. For a complete presentation of the microphysical scheme see Flossmann and Wobrock (2010).

In order to provide the model with realistic cloud condensation nuclei, we used primarily (HymRef) the aerosol number concentrations observed by aircraft measurements on 26 September 2012 (Rose et al., 2015) which took place between 100 and $150 \mathrm{~km}$ south of the precipitation event and represent the most polluted conditions encountered during the HyMeX experiment in autumn 2012. The data collected from the different instruments (for details see Sect. 3) were fitted to three log-normal distributions. The parameters for the description of the size distribution (number $N$, mean diameter $D_{\mathrm{m}}$ and standard deviation $\sigma$ ) are given in Table 1 . In order to study the role of the prevailing aerosol particle concentration in precipitation, two additional realistic case studies are performed with different aerosol concentrations. The first sensitivity study, called hereafter HymLow, uses the aerosol number concentration encountered during a flight on 27 October 2012 (during IOP16 of HyMeX), which also took place over the northern Mediterranean. IOP16 encountered the lowest particle concentration observed during the entire HyMeX experiment. The minimum and maximum pollution levels observed during autumn over the French Mediterranean coastline thus ranged from 1700 to 2900 particles $\mathrm{cm}^{-3}$. As these total numbers are both quite important, a third number concentration with lower concentration is used. This third size distribution, called Remote, represents the lowest number concentrations documented by long-term aerosol observations during autumn for the southern part of France from the nearby monitoring station puy de Dôme (Fig. 1; Venzac et al., 2009). The size distribution of 26 September is taken as reference for the following cloud simulations (hereafter called HymRef), and the other two distributions (HymLow and Remote) will be used for sensitivity tests. Figure 2a gives the distribution of the number concentration for the three scenarios. 
Table 1. Aerosol particle number distributions used for the different modelling scenarios. Each size distribution is composed of three modes (i) defined with a log-normal distribution using the number $N$, the mean diameter $D_{\mathrm{m}}$ and the standard deviation $\sigma$ parameters $(N$ in cubic centimetres and $D_{\mathrm{m}}$ in micrometres).

\begin{tabular}{lrrr|rrr|rrr}
\hline & \multicolumn{3}{c}{$\begin{array}{c}\text { HymRef (26 Sep 2012, } \\
\text { IOP7a) }\end{array}$} & \multicolumn{3}{c|}{$\begin{array}{c}\text { HymLow (27 Oct 2012, } \\
\text { IOP16) }\end{array}$} & \multicolumn{3}{|c}{$\begin{array}{c}\text { Remote (long-term obs., } \\
\text { puy de Dôme) }\end{array}$} \\
\cline { 2 - 10 } Mode $i$ & $N_{i}$ & $D_{\mathrm{m}, i}$ & $\log \sigma_{i}$ & $N_{i}$ & $D_{\mathrm{m}, i}$ & $\log \sigma_{i}$ & $N_{i}$ & $D_{\mathrm{m}, i}$ & $\log \sigma_{i}$ \\
\hline 1 & 2900 & 0.06 & 0.26 & 1400 & 0.05 & 0.26 & 150 & 0.025 & 0.146 \\
2 & 72 & 0.32 & 0.20 & 300 & 0.16 & 0.198 & 610 & 0.052 & 0.217 \\
3 & 3 & 0.72 & 0.397 & 4 & 0.72 & 0.396 & 250 & 0.135 & 0.176 \\
\hline
\end{tabular}

We know from the aircraft observations that the particle number strongly decreases in the first $3 \mathrm{~km}$ of the atmosphere (Kagkara, 2019). This exponential decrease in number concentrations was also represented in the initial conditions for each of the model simulations. For altitudes above $3 \mathrm{~km}$ the aerosol number concentration was kept constant with the values observed at $3 \mathrm{~km}$, i.e. approximately $990 \mathrm{~cm}^{-3}$ for the HymRef scenario (Fig. 2b). The analysis of the aerosol particle composition by mass spectroscopy indicated a slight predominance of insoluble matter. For the following simulations we therefore assume that aerosol particles are a mixture of soluble (ammonium sulfate, $40 \%$ ) and insoluble (silicatelike, $60 \%$ ) matter of an assumed same molecular weight of $132 \mathrm{~g} \mathrm{~mol}^{-1}$ which can act as CCN or INPs.

\section{Observations used for the comparison study}

Figure 3 gives a topographical map of the Cévennes-Vivarais region showing the locations of the different ground stations such as rain gauge, radar and disdrometer locations. In this study we use the quantitative precipitation estimates (QPE) specifically developed for the Cévennes-Vivarais region by Delrieu et al. (2014) and Boudevillain et al. (2016). Radar observations and rain gauge measurements are merged by the geo-statistical technique kriging with external drift (KED), providing hourly rainfall data with a spatial resolution of $1 \mathrm{~km}^{2}$ (see e.g. Fig. 4a). The KED precipitation analysis uses 250 hourly rain gauges and four operational weather radars of the French weather service Météo-France. This operational set-up of the Cévennes-Vivarais Mediterranean Hydrometeorological Observatory (OHMCV, Boudevillain et al., 2011) covers an area of $32000 \mathrm{~km}^{2}$. The region of Fig. 3 only shows the S-band radar positions at Nîmes and Bollène and a limited number of rain gauges restricted to the area of interest for precipitation occurring during the IOP7a event. All 31 individual tipping-bucket rain gauges from the "service de prévision des Crues du Grand - Delta" (SPC-GD, one of the 22 flood forecasting services in France), indicated in Fig. 3, recorded the rain rate with a 5 min resolution and will later be used to better understand the temporal evolution of the intensive rain event.

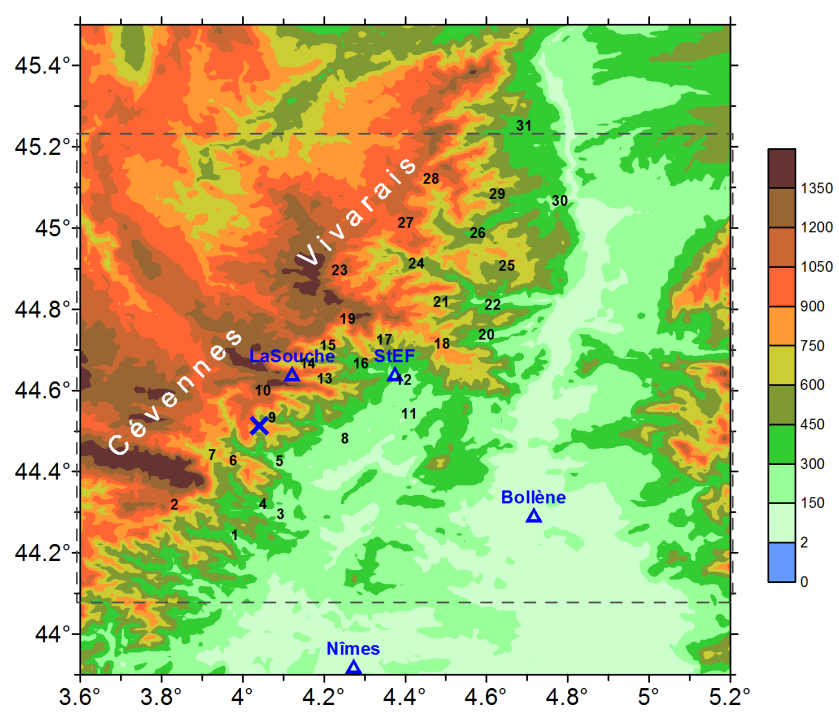

Figure 3. Topographical map of the region (altitude in metres) of strong precipitation during IOP7a. Numbers indicate the locations of rain gauges used for this study. The dotted lines show the innermost model domain. Disdrometer measurements were made at La Souche and at Saint-Étienne-de-Fontbellon (StEF), S-band radars of Météo-France are located at Nîmes and Bollène, and X-band radar is located at La Bombine indicated by the blue X.

As DESCAM explicitly simulates the spectra of cloud and rain droplets, a comparison of the modelled surface rain spectra with disdrometer measurements is also attempted. Two disdrometers, located at La Souche and Saint-Étiennede-Fontbellon (StEF) (see Fig. 3), encountered strong precipitation during IOP7a. All rain spectra were measured by OTT Parsivel ${ }^{2}$ disdrometers with a time resolution of $1 \mathrm{~min}$. The observed size distributions described in Sect. 5 were corrected following the method proposed by Raupach and Berne (2015). Observations with a fast-scanning small-range $\mathrm{X}$-band radar were also included in our comparison as they provide spatially and temporally highly resolved reflectivity fields $(60 \mathrm{~m}$ in radial direction, $30 \mathrm{~s}$ for one PPI (plan position indicator)) and thus give insights into the small-scale dynamics of the precipitating system. The X-band observations used for this study stem from the X3 radar at La Bombine 


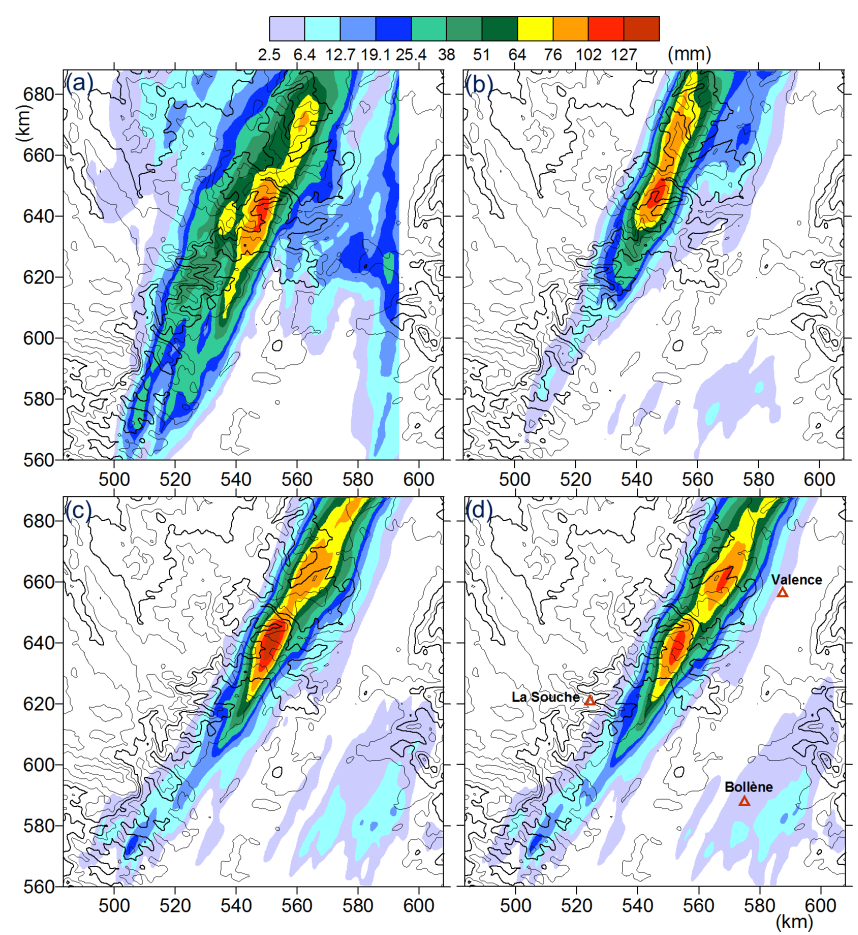

Figure 4. Observed and simulated rain accumulation for 26 September 2012, at 11:00 UTC. Panel (a) corresponds to the observations (i.e. KED analysis), (b) to the simulation using HymRef, (c) to the simulation Remote and (d) to the simulation HymLow.

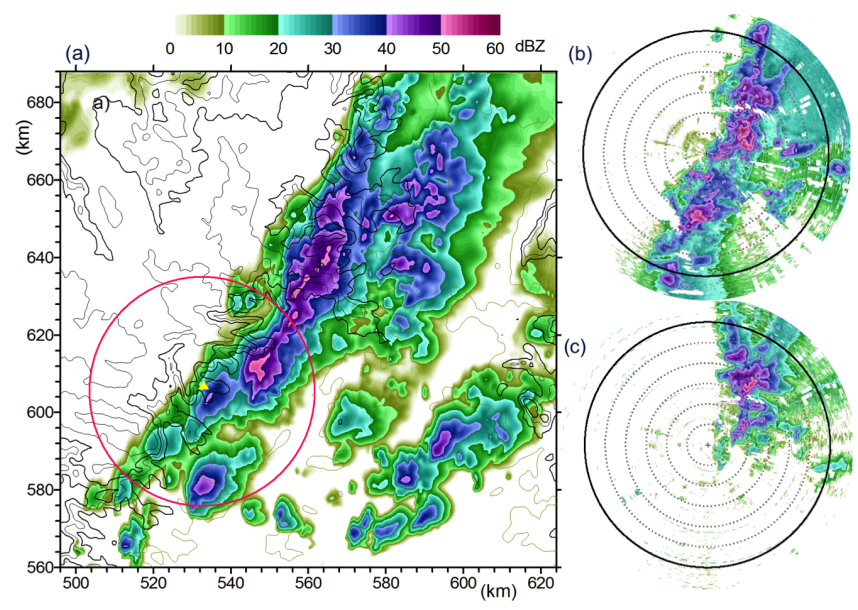

Figure 5. X-band radar reflectivity simulated for the HymRef scenario at 07:50UTC (a) and observed by the X3 radar at 07:50 UTC (b) and at 09:06 UTC (c). The red circle in (a) displays the $30 \mathrm{~km}$ radius range of the $\mathrm{X}$-band observations.

located at the north-west rim of the Cévennes (Fig. 3) at an altitude of $975 \mathrm{~m}$. Its PPI coverage is restricted to a single elevation of $1.5^{\circ}$ and its horizontal range is $36 \mathrm{~km}$ (see Fig. 5).

The number concentrations of aerosol particles were measured during numerous IOPs of HyMeX by the French research aircraft ATR-42 (Rose et al., 2015). The aeroplane was equipped with an instrumental set-up including a scanning mobility particle sizer (SMPS) and a GRIMM optical particle counter (OPC). The SMPS provides particle size distributions with diameters from 20 to $485 \mathrm{~nm}$ in time intervals of $130 \mathrm{~s}$, whereas the GRIMM OPC detects particles in the size range from $300 \mathrm{~nm}$ to $2 \mu \mathrm{m}$ every $6 \mathrm{~s}$. All the size distributions were recorded at altitudes between 200 and $3700 \mathrm{~m}$.

\section{Results}

IOP7a was the most intense rainfall episode observed during HyMeX in autumn 2012 over the Cévennes-Vivarais region (Figs. 1 and 3). A low-pressure system over the British Isles favoured the development of a south-westerly flow of warm and humid air which persisted in the free troposphere up to an altitude of $8 \mathrm{~km}$. In layers above $8 \mathrm{~km}$ the flow became more westerly. The $0{ }^{\circ} \mathrm{C}$ isotherm level was situated at an altitude of $3.7 \mathrm{~km}$. In the lowest atmospheric layers (below $900 \mathrm{hPa}$ ) airflow from the south and south-eastern directions converged with the westerly flow over the coastal area of the Gulf of Lion. Consequently, convective cells developed over the south-eastern rim of the Massif Central (i.e. the relief of the Cévennes-Vivarais). The first episodes of heavy rain started shortly after 06:00 UTC almost simultaneously for rain gauges 8, 12, 21, 26 and 29. In particular these two northern stations 26 and 29 encountered heavy rain continuously until 10:30 UTC. A second intense convective period took place from 07:30 to 09:30 UTC in the area of rain gauges 9, 10, 13-15, 19 and 23 (i.e. close to the $\mathrm{X}$-band radar observational area), where rainfall varied locally for these places between 25 and $70 \mathrm{~mm}$ and lasted more than $2 \mathrm{~h}$ (details about the time evolution of local precipitation will be illustrated in Sect. 4.4).

Convective rainfall occurred until 11:00 UTC and terminated due to the arrival of a cold front which brought stratiform and less intense precipitation in the afternoon over the Cévennes-Vivarais region. For a more detailed description of the meteorological conditions, see Ducrocq et al. (2014). Figure 5a-c show simulated and observed X-band radar reflectivity fields obtained for a beam elevation of $1.5^{\circ}$. Radar reflectivity in Fig. 5a is calculated from the results of simulation HymRef for the innermost domain, using the sixth moment of the modelled hydrometeor size distribution to determine the radar reflectivity factor $Z_{\mathrm{dBZ}}$ (Planche et al., 2010). Here $Z_{\mathrm{dBZ}}$ at 07:50 UTC was selected, as it reflects the predominant orientation and the spatial distribution of the precipitating cells over the northern Cévennes and the Vivarais well.

The X-band radar observations only cover the southwestern part of the innermost model domain and allow the comparison for a quite limited area of precipitation (marked by the circular surface of $60 \mathrm{~km}$ in diameter) encountered during IOP7a. Reflectivity observed at 07:50 UTC (Fig. 5b) shows that precipitating cells have the same orientation as 
in the model. Compared to the measurements the modelled rain band inside the radar range is slightly shifted to the east, and the convective cells south from the radar position are less important than the observed one. For the simulation HymRef the formation of the convective cells starts (at 07:20 UTC) in this southern range of the radar but rainfall is still weak. Rain gauge observations however indicate that strong convective showers already occurred 20 to $30 \mathrm{~km}$ south of the radar location.

Figure 5c shows the convective cells that develop around 09:00 UTC during the second convective period. Strong convection formed at this time further to the north, next to the radar location, and cells propagate in the northward direction. This deviation from the dominantly south-western track of rain cells could not be reproduced in the model. The vertical structure of the simulated cloud and rain field is illustrated in Fig. 6a and b. Both figures show the same vertical cross section for the innermost domain reaching from the southern border (at $x=529, y=560 \mathrm{~km}$ ) to the northern limit (at $x=579, y=688 \mathrm{~km}$ ). Figure 6 a gives the ice water content (IWC), and Fig. $6 \mathrm{~b}$ gives the rainwater content (RWC) for values larger than $0.1 \mathrm{~g} \mathrm{~m}^{-3}$. For the calculation of the RWC from the modelled drop size distribution, only drop sizes larger than $100 \mu \mathrm{m}$ were considered. The illustration in Fig. 6b shows a quite continuous rain field during the intense rain episode at 08:20 UTC. Important RWC of 2$2.5 \mathrm{~g} \mathrm{~m}^{-3}$ mainly forms close to the melting level. The $0{ }^{\circ} \mathrm{C}$ levels varied due to the strong vertical motion over the complex terrain between altitudes from 3.3 and $3.7 \mathrm{~km}$. We can also detect in Fig. 6b that raindrops appear in elevated layers up to $-20^{\circ} \mathrm{C}$. The IWC, however, reached much higher altitudes, but the presence of ice values larger than $1 \mathrm{~g} \mathrm{~m}^{-3}$ rarely exceeded a height of $8 \mathrm{~km}$, which is in agreement with aircraft in situ and cloud radar observations performed during the same time period. The illustration of the field of IWC indicates that the cloud system mainly developed to midtropospheric layers and convection did not exceed $7-8 \mathrm{~km}$. Thus, the tropopause level could not be attained, and consequently no anvil formation took place. Figure $6 \mathrm{a}$ also includes two contour lines for relative humidity of $90 \%$ and $98 \%$. The high humidity in the lower layers is caused by the southern flow from the nearby Mediterranean Sea. Relative humidity of $90 \%$ appears around $1000 \mathrm{~m}$ a.s.l. and $98 \%$ for 200 to $300 \mathrm{~m}$ above. Cloud base height, i.e. the formation of cloud droplets, is located at altitudes around $1200-1300 \mathrm{~m}$.

The formation of the convective system was triggered by orographic lifting over the Cévennes-Vivarais Mountains. The rapid cloud formation and intensification was in addition favoured by the high vapour loading in the lower atmospheric layers, arriving from the warm Mediterranean Sea and persisting for several hours. In the following sections we will compare the model results with the surface observations of rain accumulation, rain rates and droplet spectra and also address the differences in the model results for the three aerosol scenarios.

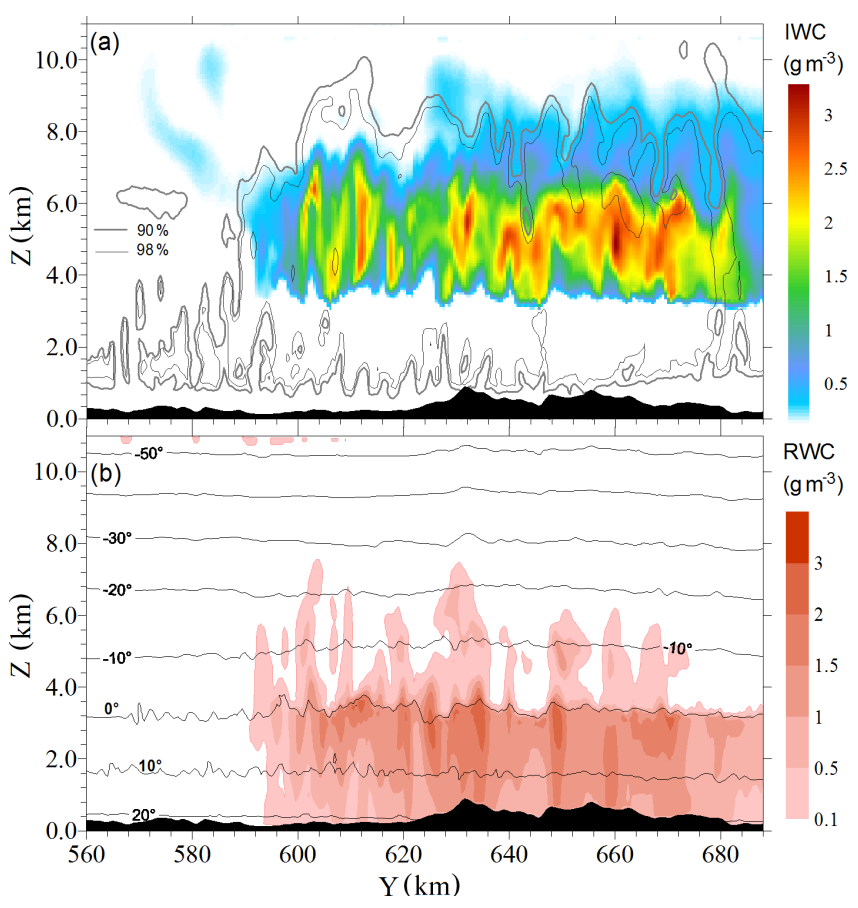

Figure 6. Vertical cross section of (a) modelled ice water content (IWC) and (b) modelled rainwater content (RWC) along the main precipitation field for the innermost model domain at 08:20 UTC. The isocontours in (a) also indicate the regions with relative humidity larger than $90 \%$ and $98 \%$; isotherms in degrees Celsius are depicted in (b). The cross section is oriented in the NNW direction and its projection on the $y$ axis presents the abscissa.

\subsection{Rain accumulation}

Figure $4 \mathrm{a}-\mathrm{d}$ show rain accumulation for the period from 06:00 to 11:00 UTC as determined by the KED analysis and simulated by the cloud model for three different scenarios of aerosol particle concentrations. Figure 4, in contrast to Figs. 1 and 3, uses the kilometric coordinates of the third model domain (i.e. the innermost domain). Precipitation after 11:00 UTC was still ongoing but appeared only very locally and with low intensity $\left(<2 \mathrm{~mm} \mathrm{~h}^{-1}\right)$. The KED results indicate that the largest rain accumulations with $115 \mathrm{~mm}$ occurred over the Vivarais Mountains. A small second maximum with $76 \mathrm{~mm}$ developed $20 \mathrm{~km}$ to the north. The location of the main maximum is reasonably reproduced by all simulations (Fig. 4b-d). Spatial deviations between observed and modelled rain maxima are within a radius of 5 to $7 \mathrm{~km}$. The orientation of the modelled rain band is quite similar to the observed one. The location of the secondary maximum in the northern precipitation field is also reproduced, especially for the simulations with the intermediate aerosol loading case (HymLow, Fig. 4d). The strongest difference between observations and model results occurs in the surface extension of rain. We note that the width of the observed rain band is much larger than the simulated one as it extends more to the west. 
This area of precipitation with a local maximum of $74 \mathrm{~mm}$ of rain at $(x, y)=(540 ; 640 \mathrm{~km})$ was caused by the second convective phase from 09:00 to 10:30 UTC which was less pronounced in all simulations.

The differences in surface rain extension between observation and model become most obvious when the total water mass of the $5 \mathrm{~h}$ rain accumulation (i.e. from 06:00 to 11:00 UTC) is calculated by integration over the entire domain displayed in Fig. 4a. Table 2 gives the surfaceintegrated total mass of rainwater resulting from the KED analysis and from the simulations HymRef, HymLow and Remote accumulated until 11:00 UTC. In Table 2, different thresholds of rain accumulation are used to calculate the precipitation amounts. When considering precipitation events with a threshold exceeding 2, 10 or $20 \mathrm{~mm}$ for each model grid point, we note that the simulated rain accumulation remains $40 \%$ to $50 \%$ smaller than the observed accumulation. Restricting however to the areas with only strong precipitation where rain accumulation exceeds $50 \mathrm{~mm}$, differences with the simulations are reduced to $10 \%$ to $20 \%$ only. This result can also be expressed in terms of the area coverage of precipitation: while the observed surface accumulation of at least $10 \mathrm{~mm}$ covers $6300 \mathrm{~km}^{2}$ according to Fig. $4 \mathrm{a}$, the model results only in $2100 \mathrm{~km}^{2}$ for HymRef and in $2700 \mathrm{~km}^{2}$ for Remote. Surface accumulation of more than $50 \mathrm{~mm}$, however, was observed for an area of $1060 \mathrm{~km}^{2}$, while the simulated areas are close with 700 to $820 \mathrm{~km}^{2}$ depending on the scenario (HymRef and Remote, respectively).

\subsection{Spatial and time evolution of the rain field}

The QPE, determined by means of the KED technique, provides the rain accumulation on an hourly basis. Figure $7 \mathrm{a}$ illustrates the hourly rain accumulation between 07:00 and 11:00 UTC. Four surfaces coloured in red, green, orange and blue display the temporal shift of the rain field from the east to the west in increments of $1 \mathrm{~h}$. The coloured surfaces delimit regions with rain accumulation larger than $20 \mathrm{~mm} \mathrm{~h}^{-1}$.

Figure $7 \mathrm{~b}$ and $\mathrm{c}$ show the same results for the simulation with the strongest (HymRef) and the weakest aerosol loading (Remote). We can see that the shift of the rain field from 07:00 to 11:00 UTC is less pronounced than in the KED analysis of Fig. 7a. This is again a consequence of the underestimated second convection zone to the west and to the south as already indicated in Sect. 4.1. Furthermore, it becomes evident that regions with maximum rain accumulation are those where rain lasted for more than 2 or $3 \mathrm{~h}$. Figure $7 \mathrm{c}$ shows that the rain pattern is mostly steady state in the Remote case, which finally results in the strongest rain accumulation as already noted in Table 2 . At the end of the three different scenarios, as described in Sect. 4.1, the spatial rain accumulation field shows some differences, especially in the location of their maximum. The Taylor diagram (Fig. 8) visualizes the skills of the different scenarios in simulating the rain accumulation field. The HymRef scenario simulates the spatial

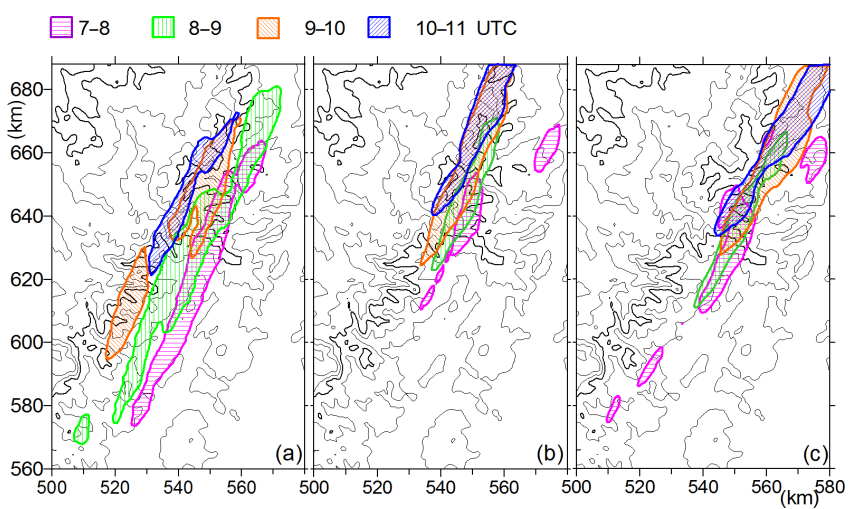

Figure 7. Surface areas with hourly rain $>20 \mathrm{~mm}$. Results from the KED analysis are presented in (a), the model results for scenario HymRef in (b), and those for scenario Remote in (c).

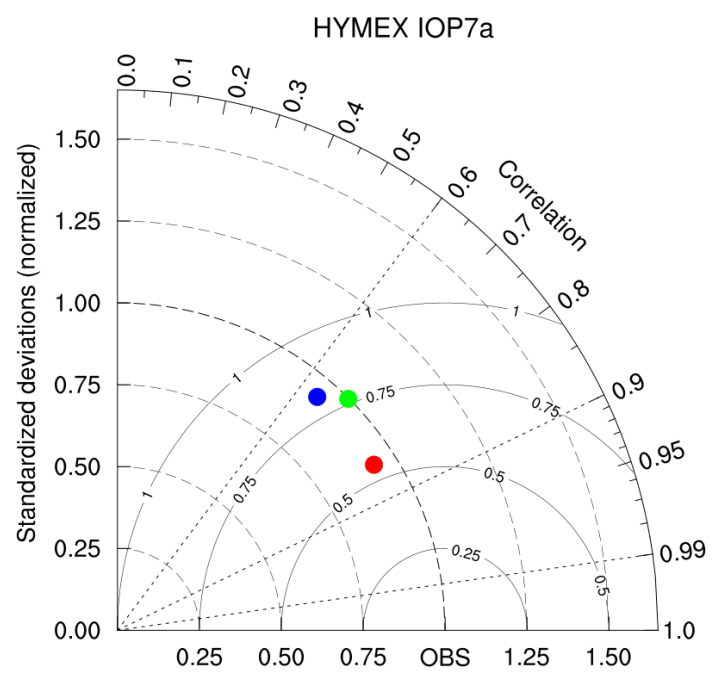

Figure 8. Taylor diagram for the rain accumulation from the three different scenarios: HymRef (in red), HymLow (in blue) and Remote (in green). The radial coordinate shows the standard deviation of the rain field, normalized by the observed standard deviation. The azimuthal variable shows the correlation of the modelled rain accumulation field with the observed one. The distance between the reference KED data (i.e. OBS) and individual points corresponds to the root-mean-square error (RMSE).

pattern of precipitation quite well and better than the simulations using the two other aerosol particle loadings.

\subsection{The effect of the initial aerosol particle number concentration}

Comparing the results for the different simulations in Table 2 , it becomes obvious that the total rain mass is highest for the Remote aerosol particle distribution, then decreases for the HymLow case where aerosol particle number increased by a factor of 2 and is the lowest for the highest aerosol number concentration of HymRef. The last line in 
Table 2. Total mass of rainwater (in megatonnes) recorded and simulated for the period from 06:00 to 11:00 UTC, 26 September 2012 for different thresholds of rain accumulation. The bottom line gives the local maximum values occurring for observed and simulated rain accumulation (in millimetres).

\begin{tabular}{lrrrr}
\hline Rain amount & $\begin{array}{r}\text { Observation (KED } \\
\text { analysis) }(\mathrm{Mt})\end{array}$ & $\begin{array}{r}\text { HymRef } \\
(\mathrm{Mt})\end{array}$ & $\begin{array}{r}\text { HymLow } \\
(\mathrm{Mt})\end{array}$ & $\begin{array}{r}\text { Remote } \\
(\mathrm{Mt})\end{array}$ \\
\hline$>2 \mathrm{~mm}$ & 209.9 & 102.3 & 117.0 & 121.4 \\
$>10 \mathrm{~mm}$ & 190.3 & 83.9 & 97.8 & 101.7 \\
$>20 \mathrm{~mm}$ & 149.0 & 73.7 & 86.1 & 87.7 \\
$>50 \mathrm{~mm}$ & 69.7 & 52.4 & 58.9 & 63.2 \\
\hline Max $(\mathrm{mm})$ & 116 & 118 & 117 & 150 \\
\hline
\end{tabular}

Table 2 gives the observed and simulated maxima of rain accumulation. The maximum of rain accumulation for Remote, i.e. the cleanest atmospheric conditions, exceeds the results for HymRef and HymLow considerably.

The increase in rain accumulation with decreasing initial aerosol concentration is associated with an increase in strength and intensity of the main rain field to the south due to an earlier onset of rain and an intensification of the rain amount in zones with weak precipitation (see for example isolated rain area in the south-eastern corner of the model domain in Fig. 4). The differences in rain accumulation for the three aerosol scenarios result from the activation and condensation processes in the initial phase of cloud development, which is driven by the number concentration of cloud condensation nuclei. Under atmospheric conditions with low particle concentrations, droplets can form precipitation more rapidly as the field of water vapour supersaturation becomes stronger (Planche et al., 2010). Consequently, the development of the ice microphysical processes and the latent heat release are also modified causing changes in the dynamical development of the simulated cloud.

Detailed studies of the effect of aerosol particle number and solubility on precipitation formation have already been carried out with the same dynamical-microphysical model DESCAM for individual short-lived convective systems over central Europe (Planche et al., 2010) as well as over Florida (Leroy et al., 2009). In these previous studies the rain duration was much shorter $(<30 \mathrm{~min})$ and accumulation did not exceed $30 \mathrm{~mm}$. The results of the present study for orographically generated and long-lasting steady-state convection confirm our previous findings: more rain occurs when low particle numbers prevail.

Figure 9 displays the spatial frequency distribution (PDF) of observed and simulated $5 \mathrm{~h}$ integrated rain accumulation in the range from 10 and $150 \mathrm{~mm}$. The comparison of this distribution function displays a reasonable similarity between simulations and KED analysis, i.e. a strong decreasing trend of the frequency with increasing rain intensity. A closer look at Fig. 9 confirms the previous results that the underestimation of simulated rain mainly occurs in the range of weak to medium accumulation, i.e. from 15 to $40 \mathrm{~mm}$ (note the log-

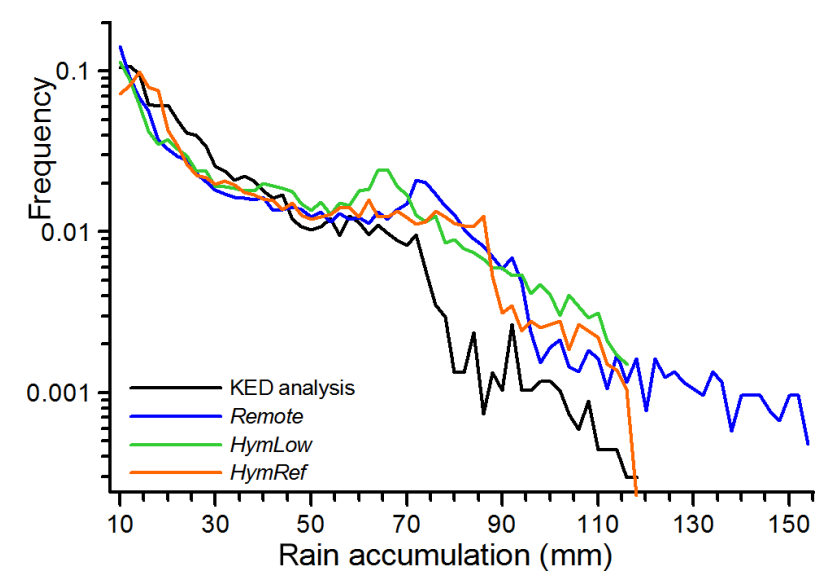

Figure 9. Normalized occurrence of observed and simulated rain accumulation from 06:00 to 11:00 UTC. The bin size for the rain accumulation is $2 \mathrm{~mm}$. Note the logarithmic frequency axis.

arithmic axis of Fig. 9). In addition, we can detect that the frequency of rain events $>70 \mathrm{~mm}$ is higher than in the KED analysis for all model results.

The differences in the frequency distribution between the three aerosol cases Remote, HymLow and HymRef confirm the role of the particle number concentration in the amount of the rain accumulation. Using the number concentration for Remote conditions, a rain accumulation of up to $154 \mathrm{~mm}$ is simulated by the model. The number of grid points with more than $120 \mathrm{~mm}$ remains however quite low $(0.1 \%$ of the simulated rain surface). For the two simulations with the higher particle concentrations observed during HyMeX (HymLow and HymRef), the maximum rain accumulation does not exceed $120 \mathrm{~mm}$. However, the rainfall from the lower aerosol concentration HymLow exceeds the total rain mass from the HymRef case (see Table 2). Figure 9, thus, confirms that the increase in total precipitation is caused by an increasing number of locations with high rain accumulation (larger than $60 \mathrm{~mm})$. 


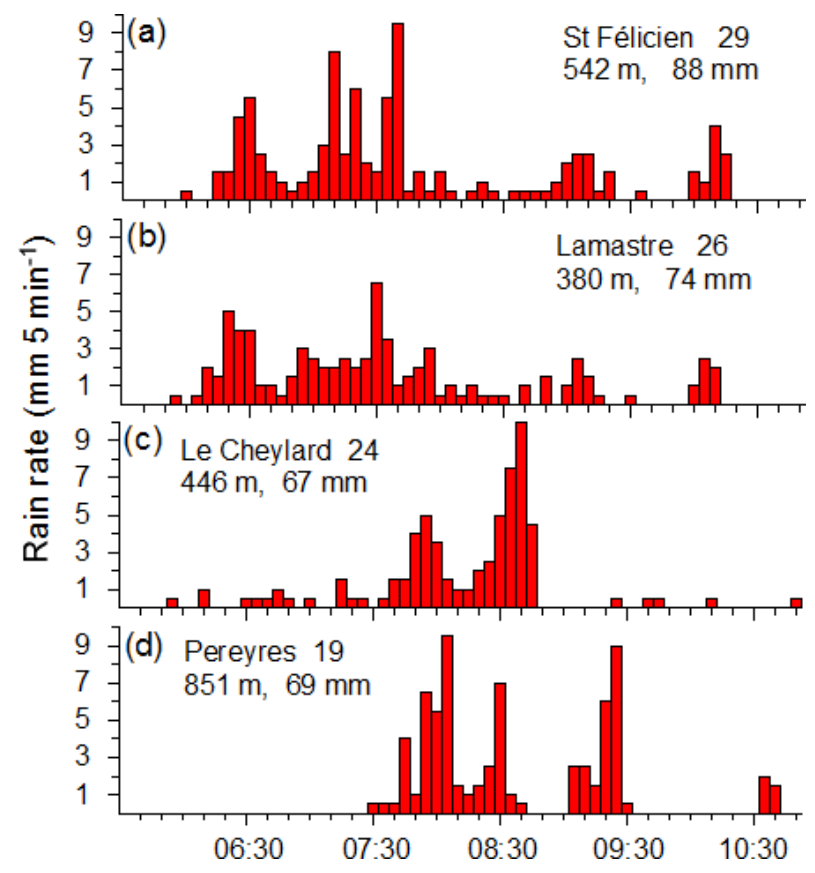

Figure 10. Temporal evolution of the $5 \mathrm{~min}$ rain rates of four observational points in Vivarais for 26 September 2012. Numbers behind the names give their location, as indicated in Fig. 3, as well as the elevation above sea level and the accumulated rain amount.

\subsection{Time evolution of local precipitation}

In a further step we evaluate the capacity of the model to reproduce the temporal variability of the rain. Therefore, we use the rain gauge measurements whose positions are indicated in Fig. 3 by the numbers 1 to 31. They recorded temporally highly resolved rain rates during 5 min intervals. Measurements for four stations with long-lasting and intense rain periods are displayed in Fig. 10. These stations are all located in the Vivarais region where the strongest rainfall occurred on this day (compare Fig. 4a). Rainfall started shortly after 06:00 UTC over the most northern stations St. Félicien (29) and Lamastre (26) (Fig. 10a and b). The first precipitation period mainly concerned the eastern part of $\mathrm{Vi}$ varais. The rain gauge of Le Cheylard (24) (Fig. 10c) collected only low quantities of rain during this initial period. At 07:30 UTC, however, another convective rain cluster formed slightly more to the west, extending from gauges 13 over 19 to gauge 24. Figure 10c and d illustrate this second important rain period for gauges 19 and 24. Radar observations for this zone reported persistent and the strongest reflectivity, resulting in the maximum rainfall in the KED analysis. Unfortunately, no other observational sites are located between gauges 17, 19, 21 and 24 confirming this maximum.

Figure 11 displays the time series of simulated 5 min rain rates for the rain gauge locations 19 and 24. Results for the HymRef scenario are given in Fig. 11a and b and those for Remote in Fig. 11c and d. Rain accumulation for the southern location 19 gave $51 \mathrm{~mm}$ in the Remote simulation and $47 \mathrm{~mm}$ in HymRef. Differences between both scenarios are more pronounced for the northern location 24, where $112 \mathrm{~mm}$ was simulated for the Remote case but only $90 \mathrm{~mm}$ for HymRef. The temporal evolution of other grid points can of course deviate from these, but the ones selected for Fig. 11 document the overall characteristics of the modelling results quite well. We note that when comparing the modelled time series (Fig. 11) with the observed ones (Fig. 10) two features are most striking:

1. the amplitudes of the observed rain rates fluctuate more than the simulated ones, which means the simulated local rain evolution shows a more continuous increase and decrease, and

2. the maxima of the observed 5 min rain rate attain higher values than in the simulations.

We detect the absence of rain rates exceeding $8 \mathrm{~mm}$ (but visible in the measurements in Fig. 10a and d) as the modelled rain rates (Fig. 11) generally stay below $4-5 \mathrm{~mm}$ every $5 \mathrm{~min}$. For this comparison, we need to consider that the model results represent rainfall over a grid box of $500 \mathrm{~m} \times 500 \mathrm{~m}$ while rain gauges have a collection surface of only about $0.04 \mathrm{~m}^{2}$. In the observations, as well as the model, however, the appearance of very strong rain events (with more than $7 \mathrm{~mm}$ every $5 \mathrm{~min}$ ) is always preceded by 15 to $20 \mathrm{~min}$ of rain of moderate intensity. The time evolutions as presented in Fig. 11 confirm that the simulated areas with strong precipitation are caused by long-lasting and continuous rain episodes, while the observations indicate stronger intensities over shorter time intervals, a feature which is sub-grid scaled in the model and, thus, cannot be confirmed.

Comparing the results of the HymRef with the Remote scenario, it becomes evident that not only the rain accumulation but also the strength of the $5 \mathrm{~min}$ rain rates increased in the presence of fewer cloud condensation nuclei. Maximum rain rates with more than $8 \mathrm{~mm}$ every $5 \mathrm{~min}$ were recorded several times by the rain gauges. Model simulations for high aerosol numbers of HymRef do not exceed rain rates larger than $6 \mathrm{~mm}$, while the simulations with the low aerosol numbers (Remote) can reach up to $9 \mathrm{~mm}$ for a few places (but not for the two grid points illustrated in Fig. 11). A frequency analysis of the $5 \mathrm{~min}$ rain rates (Fig. 12) summarizes the differences between the model scenarios and the observations. This figure confirms the presence of rain rates stronger than $6 \mathrm{~mm}$ every $5 \mathrm{~min}$ in the observations as well as its absence in the simulation HymRef with high aerosol number concentrations. The model scenario Remote can produce rain rates larger than $6 \mathrm{~mm}$, but their occurrence remains significantly rarer than the observed ones.

In addition, the frequency analysis in Fig. 12 also demonstrates that the model produced rain in the range of 1.5 to $4.5 \mathrm{~mm}$ every $5 \mathrm{~min}$ more often, which is finally responsible for the strong rain accumulation obtained in the simulations. 


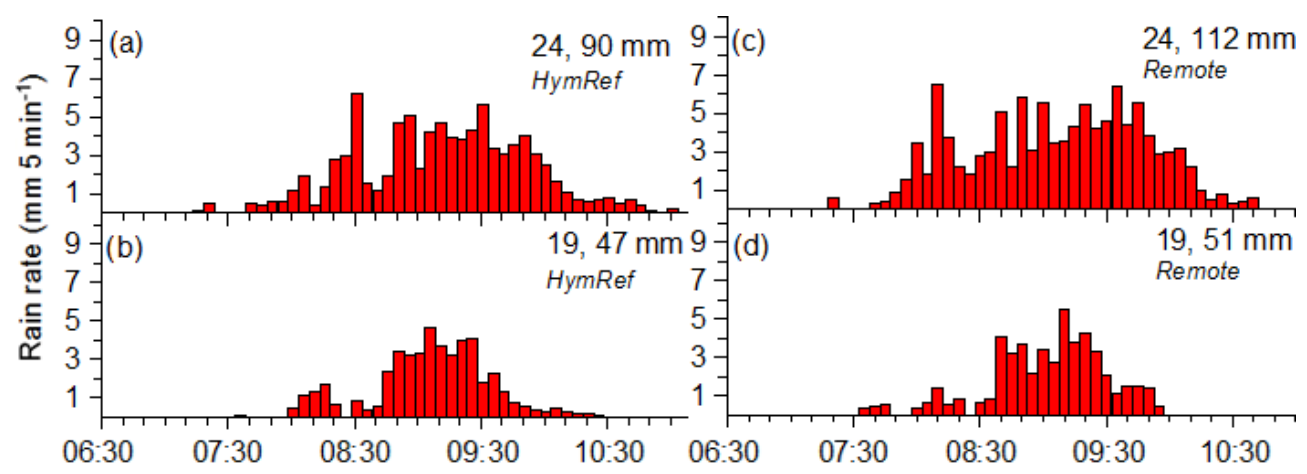

Figure 11. Time evolution of the simulated 5 min rain rates of IOP7a for scenarios HymRef (a, b) and Remote (c, d). Model results were taken for rain gauge locations 19 and 24 displayed in Fig. 3.

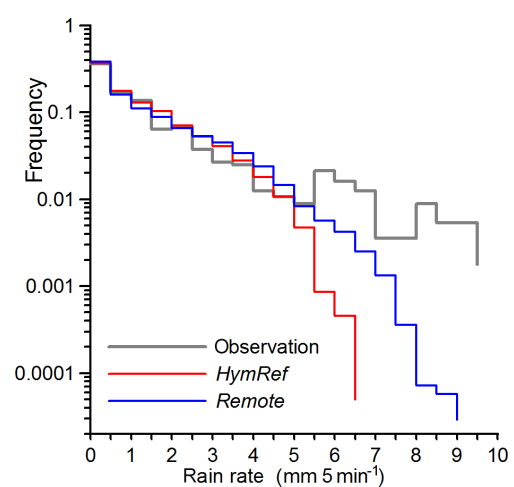

Figure 12. Normalized occurrence of the 5 min rain rate determined from 31 rain gauge observations (black line) and simulations in the third domain for HymRef (red line) and Remote (blue line).

The different scenarios lead to modified developments of the precipitation fields. In addition to a rain rate increase, we note a modification in the surface area covered by rain during the intense convective period (see Figs. 4 and 7).

\section{Comparisons at raindrop scale}

As DESCAM is a bin-resolved cloud model, we attempt a comparison between simulated and observed raindrop size distributions (RSDs) in the final step of our model evaluation. During IOP7a two disdrometers counted raindrops, one at La Souche at $950 \mathrm{~m}$ and the other at StEF at $350 \mathrm{~m}$ a.s.l. (see Fig. 3). The disdrometer at StEF recorded rain spectra from 06:30 to 07:30 UTC and the one at La Souche from 07:30 to 09:10 UTC, both with a $1 \mathrm{~min}$ time resolution. The shape of the number concentration varied essentially with total rainwater content (RWC) whose values reached up to $7 \mathrm{~g} \mathrm{~m}^{-3}$ when integrating over the observed RSD. We however restrict our analysis to the spectra below $3.5 \mathrm{~g} \mathrm{~m}^{-3}$ as such spectra already provide high rain rates from 6 to $11 \mathrm{~mm}$ every $5 \mathrm{~min}$ depending on the size of the mean mass diame-

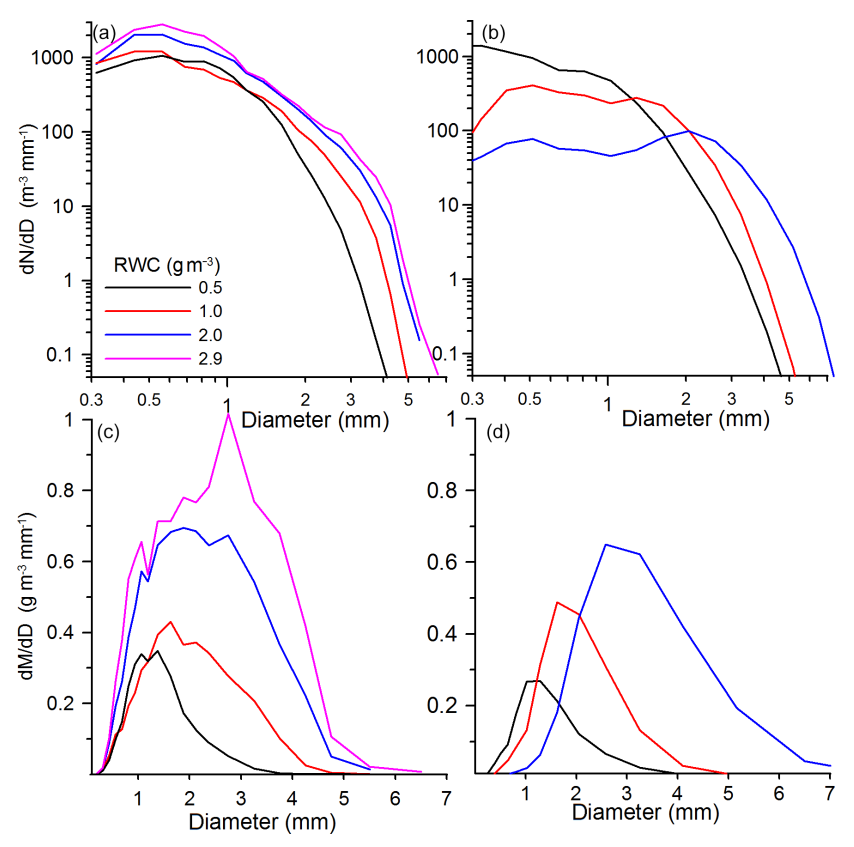

Figure 13. Number distribution functions of raindrops: (a) observed at La Souche in $950 \mathrm{~m}$ a.s.l., (b) modelled for scenario HymRef. The equivalent mass distributions for the observed spectra are given in (c) and for the modelled spectra in (d). The spectra were selected in four rainwater categories; each can deviate $\pm 20 \%$ from the given RWC value.

ter (i.e. 9 of the 70 spectra with RWC higher than $4.9 \mathrm{~g} \mathrm{~m}^{-3}$ were excluded).

Figure 13a shows the RSD of the La Souche disdrometer measurements distinguished into four categories of RWC: $0.5,1,2$ and $2.9 \mathrm{~g} \mathrm{~m}^{-3}$. The spectra displayed are averages over all RSDs for which RWC deviates $\pm 20 \%$ from the selected mean value of $0.5,1$ and $2 \mathrm{~g} \mathrm{~m}^{-3}$. However, the RSD of RWC of $2.9 \mathrm{~g} \mathrm{~m}^{-3}$ represents a mean for spectra holding 2.7 to $3.5 \mathrm{~g} \mathrm{~m}^{-3}$. Figure 13a illustrates that the increase in RWC is accompanied by the presence of larger drops. In addition, we can see for the spectra with 2 and $2.9 \mathrm{~g} \mathrm{~m}^{-3}$ the 
number of droplets $<1 \mathrm{~mm}$ is significantly higher than for the spectra with low RWC. Figure 13c displays the corresponding mass distributions of the RSD given in Fig. 13a. In order to better illustrate the mass contribution of the different drop sizes to the RWC, we plotted both axes of the mass spectra on a linear scale. At first glance we can discover that drops smaller than $1 \mathrm{~mm}$ only contribute very little to the averaged RWC, and the mean mass diameter shifts from $1.3 \mathrm{~mm}$ for the observed RSD with $0.5 \mathrm{~g} \mathrm{~m}^{-3}$ to almost $3 \mathrm{~mm}$ in the case with strong RWC of $2.9 \mathrm{~g} \mathrm{~m}^{-3}$.

Figure $13 \mathrm{~b}$ and $\mathrm{d}$ show corresponding illustrations from the model simulation. The model data used for this comparison occurred between 07:50 and 10:00 UTC. We considered simulated RSD only from surface grid points where the topographical elevation was between 900 and $1000 \mathrm{~m}$ and modelled RWC ranged around $0.5,1$ and $2 \mathrm{~g} \mathrm{~m}^{-3}$ (also within an interval of $\pm 20 \%$ ). The results are restricted to the RSD simulated by the scenario HymRef. The maximum RWC modelled in this case at this elevation never exceeded $2.4 \mathrm{~g} \mathrm{~m}^{-3}$, which explains the absence of the 2.9 curve (in the scenario Remote, which is not presented here, stronger rain events with $2.7 \mathrm{~g} \mathrm{~m}^{-3}$ between 900 and $1000 \mathrm{~m}$ were encountered).

The simulations of number and mass distribution clearly demonstrate that the sizes of the simulated raindrops increase with increasing RWC. In contrast to the observations, the number concentration for the smaller drop sizes, however, decreases with increasing RWC. This behaviour in the model is associated with the fact that large raindrops can only form through collision-coalescence with smaller precipitating drop sizes. In the simulation, cloud base is located between 1300 and $1400 \mathrm{~m}$ a.s.l., i.e. about $400 \mathrm{~m}$ above the ground, and thus no cloud droplets are present at the surface. Figure 13b illustrates this process quite well as the larger sizes increase at the cost of smaller raindrops in the range from 0.3 to $1.5 \mathrm{~mm}$. Concerning the observations, we need to keep in mind that the location of La Souche is in a mountainous region of $950 \mathrm{~m}$. We cannot exclude that the observational site was closer to cloud base or even immersed in the cloud, explaining the presence of an increased number of small raindrops. A comparison with the raindrop spectra observed at StEF at $350 \mathrm{~m}$ a.s.l. partially confirms this hypothesis as the number concentration for drops $<1 \mathrm{~mm}$ is generally a factor of 2-3 smaller (Zwiebel et al., 2016); a decrease in this number with increasing RWC, however, could also not be detected.

The comparison between observed and modelled RSD was restricted to the scenario HymRef, presenting a relatively high concentration in aerosol particles. In Fig. 14 we compare the mass distributions resulting from all three different scenarios already discussed above. In order to get a statistically reliable result, we only compare data at surface level ranging between 500 and $600 \mathrm{~m}$ as rain occurred most frequently in this elevation in the time span from 07:30 to 10:00 UTC. As a consequence, each mass spectrum is an average over 2800 to 3200 individual RSDs. Their

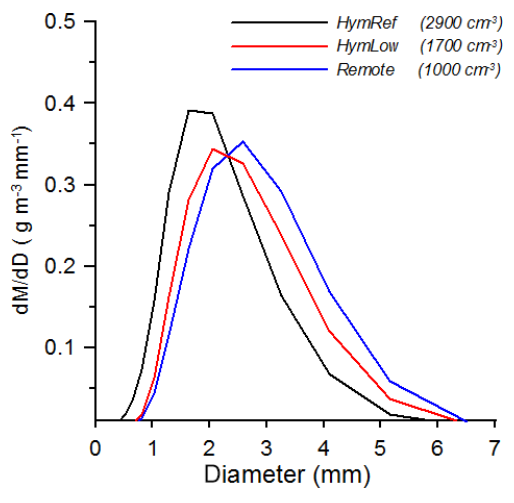

Figure 14. Mean mass distributions of raindrops simulated for all surface elevations between 500 and $600 \mathrm{~m}$ a.s.l in the third model domain.

mean RWC is $0.88 \mathrm{~g} \mathrm{~m}^{-3}$ for HymRef as well as for HymLow but $0.96 \mathrm{~g} \mathrm{~m}^{-3}$ for the Remote scenario. We note from Fig. 14 that the initial aerosol number concentration also influences the final RSD. The mean mass diameter shifts from $2.2 \mathrm{~mm}$ for HymRef to $2.9 \mathrm{~mm}$ for the lowest initial aerosol distribution (Remote). The simulation with about 1700 particles $\mathrm{cm}^{-3}$ is located between the two other cases.

\section{Summary and conclusion}

A major objective of this study was to test if a bin-resolved microphysics module in a 3D mesoscale model is successful in reproducing a real case of intense precipitation usually observed over the western Mediterranean basin. The heavy-precipitation event in the Cévennes-Vivarais region observed during the HyMeX field experiment IOP7a in autumn 2012 was selected and analysed. Results for the QPE indicate a maximum rain accumulation of $115 \mathrm{~mm}$ during $5 \mathrm{~h}$ over the Vivarais Mountains. Heavy precipitation with more than $50 \mathrm{~mm}$ covered a surface of about $1060 \mathrm{~km}^{2}$. The high quantity of rain was caused by the permanent formation of new convective cells over the same mountainous barrier.

The simulation with the bin-resolved cloud model produces the location of the rain maximum and also the surface area covered by heavy precipitation $(>50 \mathrm{~mm})$ quite well. In the surrounding regions with lower rain amounts, however, model results underestimate the rain-covered surface area by more than a factor of 2 . A comparison of the temporal development of the observed rain field shows that the triggering of convection occurred for a wider spatial spread than in the simulation. We suspect that the initial and boundary conditions imposed by the IFS/ECMWF data at 00:00 and 12:00 UTC with a grid resolution of $0.25^{\circ}$ provided a too homogeneous structure for the fields of wind, temperature and humidity. During the integration time from 00:00 to 06:00 UTC prior to convection formation, the model could not produce the small mesoscale atmospheric heterogeneities 
which exist under real conditions. These differences, e.g. in atmospheric humidity, become obvious in the temporal and spatial delayed onset of rain, as its formation starts almost $1 \mathrm{~h}$ before and $25 \mathrm{~km}$ more to the south than in the simulations (Fig. 4).

Model simulations were initialized with three different scenarios of aerosol number concentrations. For the reference case (HymRef with $2900 \mathrm{~cm}^{-3}$ ), aircraft observations of aerosols sampled $15 \mathrm{~h}$ prior to the rain events and about $150 \mathrm{~km}$ upwind of the convection formation were used. The second scenario prescribed the lowest number concentration of HyMeX in autumn 2012 with $1700 \mathrm{~cm}^{-3}$ (HymLow) sampled by aircraft measurements, and the third scenario (Remote) prescribed the lowest concentration of $1000 \mathrm{~cm}^{-3}$ available from long-term observations collected in the north of the French Massif Central. It was found that the decrease in the aerosol concentration from 2900 to $1000 \mathrm{~cm}^{-3}$ enhances rain accumulation by $20 \%$ and also the area covered by heavy precipitation (see Figs. 4 and 7). In addition, a frequency analysis of the spatial distribution of the rain accumulation shows that the gain in precipitation for low aerosol loadings is mainly caused by the increase in the number of locations with rain accumulations $>60 \mathrm{~mm}$.

In a further step of our analyses we compared the local behaviour of the modelled precipitation with measurements of 5 min rain rates sampled from 31 individual gauges. The temporal evolution of observations indicates that the highest rain rates of 5 to $9.5 \mathrm{~mm}$ every $5 \mathrm{~min}$ do not appear immediately but only after a period of weak to medium rainfall lasting at least 15 to $20 \mathrm{~min}$. Model results presented in Sect. 4.4 confirm this observational result.

After achieving their maximum, the observed rain intensities drop significantly between 5 and $9 \mathrm{~mm}$ in the following $5 \mathrm{~min}$, and thereafter rain ceases or remains low until new convective precipitating cells occur. This abrupt drop in rain rate could not be reproduced in the model. Decreasing intensities of $6 \mathrm{~mm}$ every $5 \mathrm{~min}$ can also occur in the simulations, but rainfall continues generally without intermittency. Consequently, the simulated rain rates are less fluctuating and more continuous than the observed ones, also because they represent a mean value over a $500 \mathrm{~m}$ grid, in contrast to the more localized (i.e. punctual rain gauge) observations.

Comparisons with spatially highly resolved $\mathrm{X}$-band radar observations indicate that the modelled grid resolution is not sufficient to resolve the fine-scale structure of the convective cells encountered. Consequently, the modelled convective clouds fluctuate less, and the resulting rain is of more continuous character and maximum rain rates are probably less strong than the observed ones. The analysis of the rain rate for the different aerosol scenarios also highlights differences occurring when low or high number concentrations were used. Rain intensities reach up to $9 \mathrm{~mm}$ every $5 \mathrm{~min}$ for simulations of the Remote case, while only $6 \mathrm{~mm}$ every $5 \mathrm{~min}$ was simulated when high particle concentrations were used for the HymRef scenario.
One of the main weaknesses in cloud microphysics modelling is generally the simulation of the raindrop size distribution (RSD) as most cloud models with parameterized microphysics have significant problems to realistically reproduce shape, number and mass of the RSD (Varble et al., 2014; Taufour et al., 2018; Tridon et al., 2019; Planche et al., 2019). The shape of the number and mass size distributions presented in Sect. 5 compare quite well with disdrometer measurements sampled for this precipitation event. The observations illustrate, as expected, that the RSD becomes wider with increasing rainwater content (RWC). This is also well simulated by the bin-resolved modelling. The analysis of the disdrometer measurements shows, in addition, that the number concentration of all droplet sizes (starting at diameters of $0.3 \mathrm{~mm}$ ) increases with increasing RWC. This behaviour could not be detected in the simulated spectra as the number concentration for drop diameters smaller than $1.5 \mathrm{~mm}$ decreases with increasing RWC. In order to explain these model results, we note that the simulated cloud base was located about $400 \mathrm{~m}$ above the ground. Due to the cutoff from smaller raindrops prevailing inside the cloud, the evolution of the RSD was mainly determined by collisioncoalescence, which increases the size of the large drops and reduces the number of the small ones.

RSD measurements presented in Sect. 5 are located at $950 \mathrm{~m}$ a.s.l. We cannot rule out that cloud base was sometimes below this elevation and the instrument was immersed in the cloud at least part of the time where numerous smaller drops are present. The analysis of a second disdrometer, located at $350 \mathrm{~m}$ a.s.l., supports this hypothesis. For RWC of $2 \mathrm{~g} \mathrm{~m}^{-3}$ number concentration for drop sizes from 0.3 to $1 \mathrm{~mm}$ ranged typically between 700 and $1000 \mathrm{~m}^{-3}$ and thus remains significantly below those counted for the mountain station La Souche at $950 \mathrm{~m}$. But even for this second disdrometer an important reduction in small raindrops as simulated by the model cannot be reproduced. Also, other observational studies on strong precipitation events (Raupach et al., 2019 or Thurai and Bringi, 2018) confirm the behaviour that drop size concentration typically does not decrease with decreasing drop diameter.

A possible explanation of this difference in the modelled rain spectra could be attributed to the treatment of the breakup process of large raindrop sizes in the model. At the moment only spontaneous break-up is treated according to Hall (1980) and becomes active for droplet sizes larger than $5 \mathrm{~mm}$. We cannot exclude that in particular under the conditions of strong RWC, collisional break-up is also occurring (Low and List, 1982) and the redistribution of the brokenup drops will privilege the formation of smaller drop sizes. Another possible explanation for the underestimation of the small raindrop sizes is the lack of corresponding cloud particles in elevated cloud layers. A comparison of the modelled ice particle distribution in altitudes around $-12^{\circ} \mathrm{C}$ ( or $5 \mathrm{~km}$ ) with aircraft observations indicates an underestimation of the number of ice crystals smaller than $1 \mathrm{~mm}$. A detailed compar- 
ison with airborne data in order to analyse the in-cloud features, in particular related to the ice phase, will be presented in a future work.

Finally, for the raindrop size distribution the influence of the aerosol loading can also be detected. As presented in Sect. 5, we can see that the mean mass diameter increases from $2.2 \mathrm{~mm}$ for the strong aerosol concentration of HymRef up to $2.9 \mathrm{~mm}$ for the lowest aerosol charge in the Remote scenario. Thus, the variation of 2900 to 1000 aerosol particles per cubic centimetre results in a significant modification of the mean mass diameter of the RSD. Information regarding the cloud condensation nuclei number should, thus, also be taken into account in parameterized models. However, the differences encountered for the modelling of rain accumulation, rain rate and raindrop spectra remain quite small when restricting our comparison to the aerosol concentrations (i.e. HymRef and HymLow) that really were encountered during $\mathrm{HyMeX}$. Only a further important reduction in the particle concentration to remote continental conditions highlights the potential role of the aerosol particle number.

Regarding the other objective of the current investigation, our study showed the potential of bin-resolved modelling to reproduce the heavy-precipitation periods usually observed over the Cévennes area. Even though the weaker precipitation was underestimated in the model, the peak values that would warrant an alert to the population were well represented. This bin-resolved modelling also provides a better understanding of the rain microphysics processes compared to bulk models as the microphysics is explicitly represented.

In order to improve the bulk models for routine forecast, the microphysical parameterizations should probably include a dependency on the cloud condensation nuclei distribution, as well as a possible evolution of the form of the hydrometeor spectra. Bin-resolved models like DESCAM could provide some guidance for their development.

Data availability. The data are available in the HyMeX databases: ESPRI/IPSL and SEDOO/OMP (https://mistrals. sedoo.fr/Database-Content/?project=HyMeX; HyMeX database, 2020).

Author contributions. WW and CP performed the simulations; CK, WW and CP analysed the observations and model data; AF is the LaMP PI of the MUSIC project and contributed to the paper; WW wrote the paper with the help of all the other authors.

Competing interests. The authors declare that they have no conflict of interest.

Special issue statement. This article is part of the special issue "Hydrological cycle in the Mediterranean
(ACP/AMT/GMD/HESS/NHESS/OS inter-journal SI)". It is not associated with a conference.

Acknowledgements. This work is a contribution to the HyMeX programme and MUSIC project, supported by grants ANR-14CE10014 and MISTRALS/HyMex. Christina Kagkara was funded by the MUSIC project. The model calculations have been carried out at French computer facilities of the Institut du Développement des ressources en Informatique Scientifique (IDRIS) CNRS at Orsay, the Centre Informatique National de l'Enseignement Supérieur (CINES) at Montpellier under the project A0060105056 and the Centre Régional de Ressources Informatiques (CRRI) at ClermontFerrand.

The authors acknowledge the HyMeX database teams (ESPRI/IPSL and SEDOO/OMP) for their help in accessing the data (Joël Van Baelen, Sandra Banson and Yves Pointin). The authors extend their gratitude in particular to Brice Boudevillain and the OHMCV observatory for providing the KED data, as well as to Evelyn Freney for the help regarding the information about initial aerosol population.

Financial support. This research has been supported by the Agence Nationale de la Recherche (grant no. ANR-14CE1-0014).

Review statement. This paper was edited by Christian Barthlott and reviewed by two anonymous referees.

\section{References}

Ahlgrimm, M. and Forbes, R.: Improving the Representation of Low Clouds and Drizzle in the ECMWF Model Based on ARM Observations from the Azores, Mon. Weather Rev., 142, 668685, https://doi.org/10.1175/MWR-D-13-00153.1, 2014.

Boudevillain, B., Delrieu, G., Galabertier, B., Bonnifait, L., Bouilloud, L., Kirstetter, P., and Mosini, M.: The Cevennes-Vivarais Mediterranean Hydrometeorological Observatory database, Water Resour. Res., 47, W07701, https://doi.org/10.1029/2010WR010353, 2011.

Boudevillain, B., Delrieu, G., Wijbrans, A., and Confoland, A.: A high-resolution rainfall re-analysis based on radar-rain gauge merging in the Cévennes-Vivarais region, France, J. Hydrol., 541, 14-23, https://doi.org/10.1016/j.jhydrol.2016.03.058, 2016.

Clark, T. L.: Block-iterative method of solving the non-hydrostatic pressure in terrain-following coordinates: Two-level pressure and truncation error analysis, J. Appl. Meteorol., 42, 970-983, 2003.

Clark, T. L., Hall, W. D., and Coen, J. L.: Source Code Documentation for the Clark-Hall Cloud-scale Model Code Version G3CH01, NCAR Tech., Note NCAR/TN-426+STR, 1996.

Delrieu, G., Ducrocq, V., Gaume, E., Nicol, J., Payrastre, O., Yates, E., Kirstetter, P.-E., Andrieu, H., Ayral, P.-A., Bouvier, C., Creutin, J.-D., Livet, M., Anquetin, S., Lang, M., Neppel, L., Obled, C., Parent-Du Châtelet, J., Saulnier, G.-M., Walpersdorf, A., and Wobrock, W.: The catastrophic flash-flood event of 8-9 September 2002 in the Gard region, France: A first case study for the 
Cevennes- Vivarais Mediterranean Hydrometeorological Observatory, J. Hydrometeorol., 6, 34-52, 2005.

Delrieu, G., Bonnifait, L., Kirstetter, P.-E., Boudevillain, B.: Dependence of radar quantitative precipitation estimation error on the rain intensity in the Cévennes region, France, Hydrolog. Sci. J., 59, 1308-1319, https://doi.org/10.1080/02626667.2013.827337, 2014.

Ducrocq, V., Braud, I., Davolio, S., Ferretti, R., Flamant, C., Jansa, A., Kalthoff, N., Richard, E., Taupier-Letage, I., Ayral, P. A., Belamari, S., Berne, A., Borga, M., Boudevillain, B., Bock, O., Boichard, J. L., Bouin, M. N., Bousquet, O., Bouvier, C., Chiggiato, J., Cimini, D., Corsmeier, U., Coppola, L., Cocquerez, P., Defer, E., Delanoë, J., Girolamo, P. D., Doerenbecher, A., Drobinski, P., Dufournet, Y., Fourrié, N., Gourley, J. J., Labatut, L., Lambert, D., Coz, J. L., Marzano, F. S., Molinié, G., Montani, A., Nord, G., Nuret, M., Ramage, K., Rison, W., Roussot, O., Said, F., Schwarzenboeck, A., Testor, P., VanBaelen, J., Vincendon, B., Aran, M., and Tamayo, J.: HyMeX-SOP1: The field campaign dedicated to heavy precipitation and flash flooding in the Northwestern Mediterranean, B. Am. Meteorol. Soc., 95, 1083-1100, https://doi.org/10.1175/BAMS-D-1200244.1, 2014.

Duffourg, F., Nuissier, O., Ducrocq, V., Flamant, C., Chazette, P., Delanoë, J., Doerenbecher, A., Fourrié, N., Girolamo, P. D., Lac, C., Legain, D., Martinet, M., Saïd, F., and Bock, O.: Offshore deep convection initiation and maintenance during HyMeX IOP16a heavy precipitation event, Q. J. Roy. Meteorol. Soc., 142, 259-274, https://doi.org/10.1002/qj.2725, 2016.

Fan, J., Leung, L. R., Li, Z., Morrison, H., Chen, H., Zhou, Y., Qian, Y., and Wang, F.: Aerosol impacts on clouds and precipitation in eastern China: Results from bin and bulk microphysics, J. Geophys. Res.-Atmos., 117, D00K36, https://doi.org/10.1029/2011JD016537, 2012.

Flossmann, A. I. and Wobrock, W.: A review of our understanding of the aerosol-cloud interaction from the perspective of a bin resolved cloud scale modelling, Atmos. Res., 97, 478-497, 2010.

Flossmann, A. and Wobrock, W.: Models of clouds, precipitation and storms, in: Encyclopedia of Water: Science, Technology, and Society, Atmosphere and Precipitation, Ice and Glaciers, Oceans and Coasts, Soils and Mineral Water Interface, Atmosphere and Precipitation, John Wiley \& Sons, Ltd, https://doi.org/10.1002/9781119300762.wsts0004, 2019.

Fontaine, E., Schwarzenboeck, A., Delanoë, J., Wobrock, W., Leroy, D., Dupuy, R., Gourbeyre, C., and Protat, A.: Constraining mass-diameter relations from hydrometeor images and cloud radar reflectivities in tropical continental and oceanic convective anvils, Atmos. Chem. Phys., 14, 11367-11392, https://doi.org/10.5194/acp-14-11367-2014, 2014.

Geresdi, I.: Idealized simulation of the Colorado hailstorm case: comparison of bulk and detailed microphysics, Atmos. Res., 45, 237-252, https://doi.org/10.1016/S0169-8095(97)00079-3, 1998.

Hall, W. D.: A detailed microphysical model within a twodimensional dynamic framework: model description and preliminary results, J. Atmos. Sci., 37, 2486-2506, 1980.

Hally, A., Richard, E., and Ducrocq, V.: An ensemble study of HyMeX IOP6 and IOP7a: sensitivity to physical and initial and boundary condition uncertainties, Nat. Hazards Earth
Syst. Sci., 14, 1071-1084, https://doi.org/10.5194/nhess-141071-2014, 2014.

HyMeX database: HyMeX Database Content, available at: https: //mistrals.sedoo.fr/Database-Content/?project=HyMeX, last access: 21 May 2020.

Iguchi, T., Nakajima, T., Khain, A. P., Saito, K., Takemura, T., and Suzuki, K. Modeling the influence of aerosols on cloud microphysical properties in the east Asia region using a mesoscale model coupled with a bin -based cloud microphysics scheme, based cloud microphysics scheme, J. Geophys. Res., 113, D14215, https://doi.org/10.1029/2007JD009774, 2008.

Kagkara, C.: The impact of aerosol particles and ice particles on cloud formation and precipitation: a numerical study based on the HyMeX campaign. PhD thesis, Université Clermont Auvergne, 183 pp., 2019.

Khain, A., Pokrovsky, A., Pinsky, M., Seifert, A., and Phillips, V.: Simulation of effects of atmospheric aerosols on deep turbulent convective clouds using a spectral microphysics mixed-phase cumulus cloud model. Part I: model description and possible applications, J. Atmos. Sci., 61, 2963-2982, 2004.

Koop, T. N. H. P., Luo, B., Tsias, A., and Peter, T.: Water activity as the determinant for homogeneous ice nucleation in aqueous solution, Nature, 406, 611-615, https://doi.org/10.1038/35020537, 2000.

Leroy, D., Wobrock, W., and Flossmann, A. I.: The role of boundary layer aerosol particles for the development of deep convective clouds: A high-resolution 3D model with detailed (bin) microphysics applied to CRYSTAL-FACE, Atmos. Res., 91, 62-78, 2009.

Low, T. and List, R.: Collision, Coalescence and Breakup of Raindrops. Part II: Parameterization of fragment size distributions, J. Atmos. Sci., 39, 1607-1618, 1982.

Lynn, H., Khain, A., Dudhia, J., Rosenfeld, D., Pokrovsky, A., and Seifert, A.: Spectral (bin) microphysics coupled with a Mesoscale Model (MM5). Part I: Model description and first results, Mon. Weather Rev., 133, 44-58, 2005.

Marinescu, P. J., van den Heever, S. C., Saleeby, S. M., Kreidenweis, S. M., and DeMott, P. J.: The microphysical roles of lowertropospheric versus midtropospheric aerosol particles in maturestage MCS precipitation, J. Atmos. Sci., 74, 3657-3678, 2017.

Martinet, M., Nuissier, O., Duffourg, F., Ducrocq, V., and Ricard, D.: Fine-scale numerical analysis of the sensitivity of the HyMeX IOP16a heavy precipitating event to the turbulent mixing length parameterization, Q. J. Roy. Meteorol. Soc., 143, 3122-3135, https://doi.org/10.1002/qj.3167, 2017.

Meyers, M. P., Demott, P. J., and Cotton, W. R.: New primary ice nucleation parameterizations in an explicit cloud model, J. Appl. Meteorol., 31, 708-721, 1992.

Morrison, H., Tessendorf, S. A., Ikeda, K., and Thompson, G.: Sensitivity of a simulated mid-latitude squall line to parameterization of raindrop breakup, Mon. Weather Rev., 140, 2437-2460, https://doi.org/10.1175/MWR-D-11-00283.1, 2012.

Pinty, J. and Jabouille, P.: A mixed-phase cloud parameterization for usein mesoscale non hydrostatic model: simulations of a squall line and of orographic precipitations, in: Proceedings of Conference on Cloud Physics, Everett, WA, 217-220, American Meteorological Society, Boston, MA, 1998.

Planche, C., Wobrock, W., Flossmann, A. I., Tridon, F., VanBaelen, J., Pointin, Y., and Hagen, M.: The influence of aerosol particle 
number and hygroscopicity on the evolution of convective cloud systems and their precipitation: A numerical study based on the COPS observations on 12 August 2007, Atmos. Res., 98, 40-56, 2010.

Planche, C., Tridon, F., Banson, S., Thompson, G., Monier, M., Battaglia, A., Wobrock, W.: On the realism of the rain microphysics representation of a squall line in the WRF model. Part II: Sensitivity studies on the rain Drop Size Distributions, Mon. Weather Rev., 147, 2811-2825, https://doi.org/10.1175/MWRD-18-0019.1, 2019.

Raupach, T. H. and Berne, A.: Correction of raindrop size distributions measured by Parsivel disdrometers, using a two-dimensional video disdrometer as a reference, Atmos. Meas. Tech., 8, 343-365, https://doi.org/10.5194/amt-8-3432015, 2015.

Raupach, T. H., Thurai, M., Bringi, V. N., and Berne, A.: Reconstructing the drizzle mode of the raindrop size distribution using double moment normalization, J. Appl. Meteorol. Clim., 58, 145-164, https://doi.org/10.1175/JAMC-D-18-0156.1, 2019.

Rebora, N., Molini, L., Casella, E., Comellas, A., Fiori, E., Pignone, F., Siccardi, F., Silvestro, F., Tanelli, S., and Parodi, A.: Extreme rainfall in the Mediterranean: What can we learn from observations?, J. Hydrometeorol., 14, 906-922, 2013.

Romero, R., Doswell, C. A., and Ramis, C: Mesoscale numerical study of two cases of long-lived quasi-stationary convective systems over eastern Spain, Mon. Weather Rev., 128, 3731-3751, 2000.

Rose, C., Sellegri, K., Freney, E., Dupuy, R., Colomb, A., Pichon, J.-M., Ribeiro, M., Bourianne, T., Burnet, F., and Schwarzenboeck, A.: Airborne measurements of new particle formation in the free troposphere above the Mediterranean Sea during the HYMEX campaign, Atmos. Chem. Phys., 15, 10203-10218, https://doi.org/10.5194/acp-15-10203-2015, 2015.

Sénési, S., Bougeault, P., Cheze, J.-L., Cosentino, P., and Thepenier, R.-M.: The Vaison-La-Romaine flash flood: Mesoscale analysis and predictability issues, Weather Forecast., 11, 417-442, 1996.

Seifert, A.: On the parameterization of evaporation of raindrops as simulated by a one-dimensional rainshaft model, J. Atmos. Sci., 65, 3608-3619, 2008.

Shpund, J., Khain, A., and Rosenfeld, D.: Effects of Sea Spray on the Dynamics and Microphysics of an Idealized Tropical Cyclone, J. Atmos. Sci., 76, 2213-2234, 2019.

Silvestro, F., Gabellani, S., Giannoni, F., Parodi, A., Rebora, N., Rudari, R., and Siccardi, F.: A hydrological analysis of the 4 November 2011 event in Genoa, Nat. Hazards Earth Syst. Sci., 12, 2743-2752, https://doi.org/10.5194/nhess-122743-2012, 2012.
Taufour, M., Vié, B., Augros, C., Boudevillain, B., Delanoë, J., Delautier, G., Ducrocq, V., Lac, C., Pinty, J.-P., and Schwarzenböck, A.: Evaluation of the two-moment scheme LIMA based on microphysical observations from the HyMeX campaign, Q. J. Roy. Meteorol. Soc., 144, 1398-1414, https://doi.org/10.1002/qj.3283, 2018.

Thompson, G. and Eidhammer, T.: A study of aerosol impacts on clouds and precipitation development in a large winter cyclone, J. Atmos. Sci., 71, 3636-3658, https://doi.org/10.1175/JAS-D-130305.1, 2014.

Thompson, G., Field, P. R., Rasmussen, R. M., and Hall, W. D.: Explicit forecasts of winter precipitation using an improved bulk microphysics scheme. Part II: Implementation of a new snow parameterization, Mon. Weather Rev., 136, 5095-5115, 2008.

Thurai, M. and Bringi, V. N.: Application of the generalized gamma model to represent the full rain drop size distribution spectra, J. Appl. Meteorol. Clim., 57, 1197-1210, https://doi.org/10.1175/JAMC-D-17-0235.1, 2018.

Tridon, F., Planche, C., Mroz, K., Banson, S., Battaglia, A., Van Baelen, J., and Wobrock, W.: On the realism of the rain microphysics representation of a squall line in the WRF model. Part I: Evaluation with multifrequency radar Doppler spectra observations, Mon. Weather Rev., 147, 2787-2810, https://doi.org/10.1175/MWR-D-18-0018.1, 2019.

Varble, A., Zipser, E. J., Fridlind, A. M., Zhu, P., Ackerman, A. S., Chaboureau, J.-P., Fan, J., Hill, A., Shipway, B., and Williams, C.: Evaluation of cloud-resolving and limited area model intercomparison simulations using TWP-ICE observations: 2. Precipitation microphysics, J. Geophys. Res.-Atmos., 119, 1391913945, https://doi.org/10.1002/2013JD021372, 2014.

Venzac, H., Sellegri, K., Villani, P., Picard, D., and Laj, P.: Seasonal variation of aerosol size distributions in the free troposphere and residual layer at the puy de Dôme station, France, Atmos. Chem. Phys., 9, 1465-1478, https://doi.org/10.5194/acp-9-1465-2009, 2009.

Vié, B., Pinty, J.-P., Berthet, S., and Leriche, M.: LIMA (v1.0): A quasi two-moment microphysical scheme driven by a multimodal population of cloud condensation and ice freezing nuclei, Geosci. Model Dev., 9, 567-586, https://doi.org/10.5194/gmd-9567-2016, 2016.

Zwiebel, J., Van Baelen, J., Anquetin, S., Pointin, Y., and Boudevillain, B.: Impacts of orography and rain intensity on rainfall structure. The case of the HyMeX IOP7a event, Q. J. Roy. Meteorol. Soc., 142, 310-319, https://doi.org/10.1002/qj.2679, 2016. 